\title{
Substance use among females -Study from Rural Western India
}

\section{Kajal Srivastava ${ }^{1}$, Hetal K Rathod ${ }^{2}$, Parul Sharma ${ }^{3}$, Jyoti Landge ${ }^{4}$, Shaili Vyas ${ }^{5}$, Amitav Banerjee ${ }^{6}$}

${ }^{1}$ Associate Professor, Dr. D. Y. Patil Medical College, Hospital \& Research Centre, Maharashtra; ${ }^{2}$ Professor, Dr. D. Y. Patil Medical College, Hospital \& Research Centre, Maharashtra; ${ }^{3}$ Professor, GMERS Medical College Dharpur Patan, Gujarat; ${ }^{4}$ Associate Professor, Nootan Medical College and Research Centre, Visnagar, Gujarat; ${ }^{5}$ Professor, Himalayan Institute of Medical Sciences, Swami Rama Himalayan University, Jolly Grant, Dehradun; ${ }^{6}$ Professor, Dr. D. Y. Patil Medical College, Hospital \& Research Centre, Maharashtra

\begin{tabular}{|c|c|c|c|c|c|c|c|}
\hline Abstract & Introduction & Methodology & Results & Conclusion & References & Citation & Tables / Figures \\
\hline \multicolumn{8}{|c|}{ Corresponding Author } \\
\hline \multicolumn{7}{|c|}{$\begin{array}{l}\text { Dr Hetal K Rathod (Waghela), C-14, Surobhi Enclave, Nagras Road, Aundh, Pune-411007 Maharashtra. } \\
\text { E Mail ID: } \underline{\text { hetalnwaghela@gmail.com }}\end{array}$} & 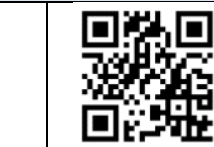 \\
\hline
\end{tabular}

\section{Citation}

Srivastava K, Rathod HK, Sharma P, Landge J, Vyas S, Banerjee A. Substance use among females -Study from Rural Western India. Indian J Comm Health. 2021;33(2):309-313.https://doi.org/10.47203/IJCH.2021.v33i02.015

Source of Funding: Nil Conflict of Interest: None declared

\section{Article Cycle}

Received: 27/11/2020; Revision: 06/04/2021; Accepted:11/05/2021; Published:30/06/2021 This work is licensed under a Creative Commons Attribution 4.0 International License.

\section{Abstract}

Background: Substance abuse is a common health problem which affects individual and takes a toll on not only person consuming it rather all members of society related to that person. Aim \& Objective: The purpose of study was to determine the prevalence of substance use among females $\&$ to know the reasons for same and association of socio-demographic profile and substance use. Settings and Design: Cross-sectional study was conducted among females attending OPD at rural health training centre of a medical college for 6 months duration. Total 500 females were interviewed for same by convenience sampling. Methods and Material: After taking informed consent from participants all the information was collected on predesigned and pretested oral questionnaire. Statistical analysis used: Qualitative Data was presented in the form of numbers and percentages. Test of significance such as chi-square was applied. Statistical analysis was done using MedCalc version 19.1 and Epi-info7. Results: Prevalence of substance use was found very high as 74\%. Most common form of substance use was tobacco chewing at $77.03 \%$. Abuse was maximum among females educated up to primary level (82.3\%). Near about $72.7 \%$ were using substance out of curiosity. $84.32 \%$ were interested in quitting abuse. Conclusions: Substance use prevalence was very high affecting health of females adversely.

\section{Keywords}

Females; Substance Use; Rural.

\section{Introduction}

Substance abuse is a major public health problem. According to National Survey on drug use and health among women 2018, in United states about 7.2 million females above 18 years use different substances and 32.1 million females were having mental or substance use disorder.(1) The prevalence of use of any drug was found to be $63.7 \%$ and tobacco was found to be most commonly abused substance (56\%).(2)

Although substance abuse among females is not a new phenomenon, in rural areas usually females also use different forms of drugs on various festive occasions. But this problem is gaining momentum in recent years because of industrialization and social and peer pressure and disturbed family life. Although smoking by women is considered bad in the Indian society $(3,4)$ consumption of smokeless tobacco and use of mishri (tobacco containing teeth cleaning powder) is very common. $(5,6)$ Females form a vulnerable group due to various factors like their poor status in society, illiteracy, burden of child birth,anaemia, malnutrition, poverty, multiple pregnancies and gender inequality on their part.(7) Females are usually not aware about the harmful effects of different substance on their health and health of unborn child during pregnancy, as adequate legislative measures are lacking. $(8,9)$ According to the WHO, substance abuse is "persistent or sporadic drug use inconsistent with or unrelated to acceptable medical practice" (WHO, 1994)".(10) Data from Asia is scanty and 
where available limited in focus. Caregivers do not recognize the problem there by limiting treatment seeking.(11,12) Pregnant women in India who used smokeless tobacco have a threefold increased risk of stillbirth and a two to threefold increased risk of having a low birth weight infant.(13) The present study was undertaken to address the gap in information with objective to know the prevalence of use of different substances among females of field practice area, association with different socio-demographic factors and reasons for abuse as well.

\section{Aims \& Objectives}

1. To determine the prevalence of substance use (all kind including alcohol) among females.

2. To know the reasons for same and association of socio-demographic profile and substance use.

\section{Material \& Methods}

A cross- sectional study was planned in rural field practice area of a tertiary care hospital \& medical college. Study was done in rural field practice area of a medical college. Study population was females more than 15 years. Females $>15$ years who visited outpatient department of RHTC \& gave consent to participate in study were included. Study lasts for 6 months duration. The sample size calculated using Win-Pepi software with proportion of substance use from a study in rural Chhattisgarh was taken as $54.5 \%$ (11) with 5\% allowable error and 95\% confidence limits it came out to be 382 . Total 500 females from rural areas were included in study. Inclusion criteria were age more than 15 years and who were given consent while those unwilling or bed ridden or suffering from mental illness or mentally incapable of understanding the questions were excluded from study. Convenience sampling technique was used to select study population. All those persons who ever used tobacco for more than a month during their life time were considered tobacco users. Written informed consent was taken. Ethical clearance from institutional ethical committee were taken before start of study. All data was entered in MS-Excel. Qualitative Data was presented in the form of numbers and percentages, quantitative data in the form of mean and standard deviation. Statistical analysis: done using MedCalc version 19.1 and Epi-info7. Test of significance such as chi-square was applied. All the information was collected on predesigned and pretested oral questionnaire which has data on socio-demographic data and questions related to type of substance use, age of starting, duration of use, reasons for starting it and regarding quitting this habit. The participants who were found to be addicted to one or more substance were sent to Psychiatry department for counseling.

\section{Results}

Mostly females $42.4 \%$ were in $20-30$ years age group. Hinduism $89 \%$ was most common religion found. Mostly females were educated up to primary level i.e.71.2\% $84.8 \%$ females were house maker. $93.6 \%$ females were married, (88.2\%) belonged to nuclear family.

In our study prevalence of substance abuse was found very high as $74 \%$ females were using one or other form of substance. Most commonly abused substance was tobacco in smokeless form like chewing in 285 (77.03\%) people, smoked tobacco (5) was very less at $1.35 \%$. Almost 9.19\% people were using more than one substance.

Mean (SD) age for initiating substance use was 29.62 (11.61) years, while minimum reported was 10 years and maximum as 90 years and median as 27 years.

Substance use was least among females less than 20 years and was maximum in middle aged females (88.9\%) while females above 60 years i.e. Senior citizens, all (100\%) found addicted to one or more substances. As age increasing, substance use was also found to be increased which is depicted by chi-square test for trend which was highly significant. Substance use was maximum among females educated up to primary level (82.3\%), although found less in illiterate females (53.8\%) which can be explained as most of our study population were educated up to primary level, indicating poor educational level among study population.75.7\% housewives were using some substances as compared to working females (64.5\%) and the difference was statistically significant. $100 \%$ widows were using some substance while none of unmarried girl was found addictive. All persons who are having family history of cancer (100\%) are addicted to one or other substances. Most of the females 269 (72.7\%) were using substance out of curiosity other reasons 34 (9.18\%) being tooth ache, headache and pregnancy was also mentioned. Most of the females $84.32 \%$ were interested in quitting this habit of abuse.

\section{Discussion}

Prevalence of tobacco use was $74 \%$ which was comparatively high as compared to other studies. According to Global adult tobacco survey (GATS) , in Maharashtra prevalence of tobacco both smoked and smokeless is around $26.6 \%(14)$, reason may be that this GATS used multiple stage methodology, while this study uses convenience sampling which may be a reason for higher prevalence. In a study in US showed that $5 \%$ of women presently used illicit substances (12). By rapid assessment surveys in India showed $83 \%$ female drug users were using tobacco (15). A study on tobacco use among school personnel in Bihar in 2001 reported that prevalence of tobacco use among women was as high as 77.0\% (16). In study in 2012 among 41.5 million illicit drug users, more than $42 \%$ were found to be women (17). In Maharashtra around 43,180 of people have registered for deaddiction while in other study among rural adolescents prevalence of abuse was found to be $37.67 \%$ (18). In rural Chhattisgarh prevalence of tobacco use among females was $54.4 \%(11)$.In urban Delhi prevalence of abuse among 
females was 36\% (19). World Drug Report 2019 mentioned, 35 million people worldwide suffer from drug use disorders while only 1 in 7 people receive treatment. Worldwide in 2017 total 188 million were using cannabis, 53 million opioids, 29 million amphetamines and 18 million were abusing cocaine(20).

Most common form of substance use by females varies from one part to another. $77.03 \%$ females were chewing tobacco while only $1.35 \%$ were taking smoked tobacco in our study. Similar findings reported from rural Chhattisgarh where $\mathbf{7 7 . 4 \%}$ females were using smokeless tobacco(10). The smokeless tobacco use among women was $53.4 \%$. from a study in Bihar(16) .Daily tobacco use among females of rural Haryana was $17.7 \%(21)$. In western countries the alcohol use by women is more (22). In country like India consumption of alcohol is less compared to tobacco. According to NFHS-4 data women using tobacco was around $6.4 \%$ while females abusing alcohol was $1.2 \%$ (23). While in Maharashtra NFHS-4 data suggests tobacco use among females were $5.8 \%$ while alcohol use was $0.2 \%$ (24).In Maharashtra prevalence of alcohol use by males (10-75years) is approximately $10.2 \%$ while overall prevalence was $5.7 \%$ (25).The most recent round of NFHS (2016) reports the prevalence of alcohol use to be $29.2 \%$ in males and $1.2 \%$ in females. National Survey on Drug Use and Health indicates that 19.5 million females aged more than 18 years have used illicit drugs in last year (26).Opoid use during labour\& delivery increased sharply between 1999 and 2014 (27).

So overall prevalence was very high in our study as compared to national average. Although sampling bias (OPD based study) is one of the reasons for higher prevalence, another reason may be that females are using this tobacco as part of their lifestyle without being aware of that it's a kind of abuse like they are using it for rubbing on teeth in place of tooth paste and powder which may be missed during other surveys or studies.Mean age of starting substance use was 29.62 years in our study while in Akola among rural youth, it was found that $25.1 \%$ of youth had started substance use below 10 years of age(28). In our study also we found that minimum age was 10 years,this may be due to the early exposure \& availability of substance at family level. Implication of early exposure to substance use will have detoriating impact on physical health like development of cancer \& mental health issues.In one community based study in Chandigarh found that mean age of starting use of substance was 20.89 years (29). It was seen in our study that with increasing age chances of substance use was increasing. Substance use was more among females educated up to primary level, house wives and among married females. In slum area study it was found that substance use was more commonly found with joint family, parental abuse status, working status, illiteracy and school dropouts (30). All females having history of cancer in family was found to be addicted to one or more substance which was an interesting fact and this can be used to give them health education to leave this habit of substance abuse. Most common reason for abuse cited was out of curiosity in our study.Curiosity is one of the reasons, as they are not aware about the side effects of abuse. If they are educated about same, at early age, may be the abuse percentage will decrease. The abuse starts at early age in some of the families, reason may be it's a familial habit of using various substances and as child will adapt the habit due to easy availability and finds it a normal behaviour. According to study in Iranian adolescent it was found that cigarette smoking is more in persons with smokers relatives or friends in family, positive thoughts for smoking (31). Adoloscents in Delhi stated most common reason for substance use as liked by friends (57.38\%), to feel like an adult (24.6\%), and some of them mentioned: "like the feeling of substances" (13.11\%)(32)

\section{Conclusion}

Substance use prevalence specially tobacco use was found to be very high i.e.74\% among females of rural area, most important reason was out of curiosity may be because of peer pressure or use by whole family may be there. Among sociodemographic variables increasing age, education upto primary level, house wives and among married females it was more. So further qualitative study need to be planned to explore other reasons for same.

\section{Recommendation}

Substance use in any form is harmful, females are considered as backbone of the family and first teacher for their children. Her health is of utmost importance. Abuse of substances will have adverse effect on health, physically, mentally and socially. Also financial hardships will be faced by the families. Early intervention in the form of family health education and counselling will definitely have positive impact on society. All the interventions to stop tobacco use must start from the family, educational institutes and community outreach programmes.

\section{Limitation of the study}

It was a rapid appraisal to identify the prevalence and determinants of substance use. Sampling technique was convenience sampling in which only females who were willing to participate in study were included in study. Qualitative study need to be undertaken to understand problem of substance use in depth. Detailed study also required to know about resons of high prevalence among females. Such kind of study also required to be undertaken in other rural areas as well

\section{Relevance of the study}

Very few studies have exclusively focused on the substance use by females. This study is exploring hidden burden of tobacco use of rural female. Socio-cultural \& regional differences in tobacco use were explored through our study. Various aspects being explored are common 
forms of tobacco use, reasons for substance use, willingness to quit etc. Though the percentages were high due to sampling bias \& data collection bias, it throws light that there is a need to focus on this important aspect of substance use by females as the long term tobacco \& alcohol consumption will have physical, psychological \& social side effects

\section{Authors Contribution}

All authors contributed equally.

\section{References}

1. National Survey on drug use and health among women https://www.samhsa.gov/data/sites/default/files/reports/rpt232 50/5_Women_2020_01_14_508.pdf

2. Pal H, Srivastava A, Dwivedi S, Pandey A, Nath J. Prevalence of Drug Abuse in India through a National Household Survey. INT J CURR SCl. 2015;15: 103-113(E)

3. Gajalakshmi, V., Peto, R., Kanaka, T. S., \& Jha, P. Smoking and mortality from tuberculosis and other diseases in India: retrospective study of 43000 adult male deaths and 35000 controls. Lancet (London, England), 2003;362(9383), 507-515. https://doi.org/10.1016/S0140-6736(03)14109-8

4. Pednekar, M. S., \& Gupta, P. C. Prospective study of smoking and tuberculosis in India. Preventive medicine, 2007;44(6), 496-498. https://doi.org/10.1016/j.ypmed.2007.02.017

5. Gajalakshmi, C. K., Ravichandran, K., \& Shanta, V. Tobacco-related cancers in Madras, India. European journal of cancer prevention : the official journal of the European Cancer Prevention Organisation (ECP), 1996;5(1), 63-68.

6. Pratinidhi, A., Gandham, S., Shrotri, A., Patil, A., \& Pardeshi, S. Use of 'Mishri' A Smokeless form of Tobacco During Pregnancy and its Perinatal Outcome. Indian journal of community medicine : official publication of Indian Association of Preventive \& Social Medicine, 2010;35(1), 14-18. https://doi.org/10.4103/0970-0218.62547

7. WHO Library Cataloguing-in-Publication Data: Women and health: today's evidence tomorrow's agenda. I.World Health Organization. ISBN 9789241563857 (NLM classification: WA 309)

8. Tobacco Free Initiative. Geneva: WHO; 2003. World Health Organisation. World Health Assembly Resolution 56.1, The WHO Framework Convention on Tobacco Control. Available from: http://www.who.int/tobacco/framework/final text/en .

9. Khare R. Use of Mishri in day to day life of an urban slum community of ManagalwarPeth, Pune. PRESM. J Comm Health. 1993;18:77-82.

10. Reddy AP, Kumar DP, Raju BA a study on prevalence and pattern of substance abuse among street children and adolescents in the state of Andhra Pradesh, India. Indian Journal of Fundamental and Applied Life Sciences. 2014;4(3):1-14

11. Tiwari RV, Gupta A, Agrawal A, Gandhi A, Gupta M, Das M. Women and Tobacco Use: Discrepancy in the Knowledge, Belief and Behavior towards Tobacco Consumption among Urban and Rural Women in Chhattisgarh, Central India. Asian Pac J Cancer Prev. 2015;16(15):6365-73.

12. Clancy, C. (2021). Substance Abuse Among Women: Why Women Use Drugs - JourneyPure At The River. Retrieved 9 June 2021, from https://journeypureriver.com/substance-abuse-among-women/

13. Gupta, P. C., Ray, C. S. Smokeless tobacco and health in India and South Asia. Respirology (Carlton, Vic.), 2003;8(4), 419-431. https://doi.org/10.1046/j.1440-1843.2003.00507.x

14. Who.int. 2021 [cited 9 June 2021]. Available from: https://www.who.int/tobacco/surveillance/survey/gats/GATS Ind ia 2016-17_FactSheet.pdf

15. Murthy P, editor. Women and drug use in India. Substance, women and high risk assessment study: United Nations Office on Drugs and Crime, Ministry of Social Justice and Empowerment, Government of India and United Nations Development Fund for Women. 2008
[Original Substance...] | Srivastava $\mathrm{K}$ et al

16. Sinha DN, Gupta PC, Pednekar MS, Jones JT, Warren CW. Tobacco use among school personnel in Bihar, India. Tob Control 2002;11(1): 82-83

17. Grucza, R. A., Norberg, K., Bucholz, K. K., \& Bierut, L. J. Correspondence between secular changes in alcohol dependence and age of drinking onset among women in the United States. Alcoholism, clinical and experimental research, 2008;32(8), 14931501. https://doi.org/10.1111/i.1530-0277.2008.00719.x

18. JasaniPK,Jadeja YM, Patel NM, Jadeja DY, Shrimali JB, Purani SK. Jasani PK et al. Int J Community Med Public Health. 2019;6(5):19701974

19. KhokharA . A Study on Substance Abuse among Women from an Urban Locality of Delhi. Indian Journal of practicing doctor.2008;5(5):11-12.

20. United Nations office on Drugs and Crime. World Drug Report 2019. Available at: https://www.unodc.org/unodc/en/frontpage/2019/June/worlddrug-report-2019

21. Gupta V, Yadav K, Anand K. Patterns of tobacco use across rural, urban, and urban-slum populations in a north Indian community. Indian J Community Med. 2010;35(2):245-51..

22. Wilsnack $S$, Wilsnack R. International Gender and Alcohol Research: Recent Findings and Future Directions. NIAAA. 2003. Available from: $\quad$ http://pubs.niaaa.nih.gov/publications/arh26-4/245250.htm [Last accessed on 25.06.2021]

23. National Family Health Survey-4. International Institute for Population Sciences (IIPS). National Family Health Survey (NFHS-4), 2015-16, India: Key Findings. Mumbai: IIPS. http://rchiips.org/NFHS/pdf/NFHS4/India.pdf

24. National Family Health Survey-4. International Institute for Population Sciences (IIPS). National Family Health Survey (NFHS-4), 2015-16, India: Key Findings. Mumbai: IIPS. http://rchiips.org/NFHS/pdf/NFHS4/MH FactSheet.pdf

25. http://socialjustice.nic.in/ [cited 9 June 2021]. Available from: http://socialjustice.nic.in/writereaddata/UploadFile/Magnitude S ubstance Use_India_REPORT.pdf

26. Center for Behavioral Health Statistics and Quality. Results from the 2016 National Survey on Drug Use and Health: Detailed Tables. Rockville, MD: Substance Abuse and Mental Health Services Administration; 2017. https://www.samhsa.gov/data/sites/default/files/NSDUHDetTabs-2016/NSDUH-DetTabs-2016.pdf (Last accessed on 25.06.2021).

27. Haight, S. C., Ko, J. Y., Tong, V. T., Bohm, M. K., \& Callaghan, W. M. Opioid Use Disorder Documented at Delivery Hospitalization United States, 1999-2014. MMWR. Morbidity and mortality weekly report, 2018;67(31), 845-849. https://doi.org/10.15585/mmwr.mm6731a1

28. Pawar RD, MehendaleAM. A cross sectional study on magnitude and pattern of substance abuse among youth in rural India. Indian Journal of Forensic and Community Medicine, July-September 2017;4(3):209-215.

29. Chavan, B. S., Arun, P., Bhargava, R., \& Singh, G. P. Prevalence of alcohol and drug dependence in rural and slum population of Chandigarh: A community survey. Indian journal of psychiatry,2007;49(1), 44-48. https://doi.org/10.4103/00195545.31517

30. Sarangi, L., Acharya, H. P., \& Panigrahi, O. P. Substance abuse among adolescents in urban slums of sambalpur. Indian journal of community medicine : official publication of Indian Association of Preventive \& Social Medicine, 2008;33(4), 265-267. https://doi.org/10.4103/0970-0218.43236.

31. Mohammadpoorasl, A., Nedjat, S., Fakhari, A., Yazdani, K., Rahimi Foroushani, A., \& Fotouhi, A. Smoking stages in an Iranian adolescent population. Acta medica Iranica, 2012;50(11), 746-754.

32. Daniel LT, Krishnan G, Gupta S. A study to assess the prevalence and pattern of substance use among male adolescents in suburban area of Delhi. Indian J Soc Psychiatry 2017;33(6):208-12. 


\section{Tables}

TABLE 1 PREVALENCE OF SUBSTANCE USE AMONG FEMALES

\begin{tabular}{|l|l|l|}
\hline Variable & $N(\%)$ & $95 \%$ C.L. \\
\hline $\begin{array}{l}\text { Substance use } \\
\text { Yes }\end{array}$ & $370(74 \%)$ & $69.98 \%-77.65 \%$ \\
No & $130(26 \%)$ & $22.35 \%-77.65 \%$ \\
\hline
\end{tabular}

TABLE 2 ASSOCIATION OF SUBSTANCE USE WITH SOCIO-DEMOGRAPHIC VARIABLES

\begin{tabular}{|c|c|c|c|c|}
\hline \multirow{2}{*}{$\begin{array}{l}\text { Variables } \\
\text { Age category }\end{array}$} & \multicolumn{4}{|l|}{ Substance use } \\
\hline & Yes & No & Total & Test of Significance \\
\hline$<20$ years & $3(18.8 \%)$ & $13(81.2 \%)$ & $16(3.2 \%)$ & \multirow{5}{*}{$\begin{array}{l}\text { Chi-square test for linear } \\
\text { Trend (Extended Mantel-haenszel)-7.67 } \\
P<0.005\end{array}$} \\
\hline 20-40years & $115(54.2 \%)$ & $97(45.8 \%)$ & $212(42.4 \%)$ & \\
\hline 40-60years & $160(88.9 \%)$ & $20(11.1 \%)$ & $180(36.0 \%)$ & \\
\hline$>60$ years & $92(100 \%)$ & $0(0 \%)$ & $92(18.4 \%)$ & \\
\hline Total & $370(74.0 \%)$ & $130(26.0 \%)$ & 500 & \\
\hline \multicolumn{4}{|l|}{ Religion } & \multirow{4}{*}{$\begin{array}{l}\text { Chi-square test } \\
8.978 \\
P=0.002 \\
\text { Odds Ratio=2.5 } \\
95 \% \text { C.I.(1.38 to } 4.40)\end{array}$} \\
\hline Hindu & 339 (76.18\%) & $106(23.82 \%)$ & $445(89 \%)$ & \\
\hline Others & $31(56.36 \%)$ & $24(43.64 \%)$ & $55(11 \%)$ & \\
\hline Total & $370(74.0 \%)$ & $130(26.0 \%)$ & 500 & \\
\hline \multicolumn{5}{|l|}{ Education } \\
\hline Higher Secondary & $14(51.9 \%)$ & $13(48.1 \%)$ & 27 (5.4\%) & \multirow{4}{*}{$\begin{array}{l}\text { Chi-square test } \\
44.341 \\
P<0.0001\end{array}$} \\
\hline Primary & $293(82.3 \%)$ & $63(17.7 \%)$ & $356(71.2 \%)$ & \\
\hline Illiterate & $63(53.8 \%)$ & $54(46.2 \%)$ & $117(23.4 \%)$ & \\
\hline Total & $370(74.0 \%)$ & $130(26.0 \%)$ & 500 & \\
\hline \multicolumn{5}{|l|}{ Occupation } \\
\hline Housewife & $321(75.7 \%)$ & $103(24.3 \%)$ & $424(84.8 \%)$ & \multirow{3}{*}{$\begin{array}{l}\text { Chi-square test } \\
4.219, \mathrm{P}=0.04 \text {, Odds ratio, } 1.7295 \% \text { C.I ( } 1.01 \text { to } 2.88 \text { ) }\end{array}$} \\
\hline Working & $49(64.5 \%)$ & $27(35.5 \%)$ & $76(15.2 \%)$ & \\
\hline Total & $370(74.0 \%)$ & $130(26.0 \%)$ & 500 & \\
\hline \multicolumn{5}{|l|}{ Marital Status } \\
\hline Married & $365(78.0 \%)$ & $103(22.0 \%)$ & $468(93.6 \%)$ & \multirow{3}{*}{$\begin{array}{l}\text { Chi-square test } \\
57.35, \mathrm{P}<0.0001 \text {, Odds ratio } 19.1495 \% \mathrm{C} .1(7.51 \text { to } 56.75)\end{array}$} \\
\hline Single* & 5 & 27 & $32(6.4 \%)$ & \\
\hline Total & $370(74.0 \%)$ & $130(26.0 \%)$ & 500 & \\
\hline \multicolumn{5}{|c|}{ Family history of cancer } \\
\hline Yes & $35(100.0 \%)$ & $0(0.0 \%)$ & $35(7.0 \%)$ & \multirow{3}{*}{$\begin{array}{l}\text { Fisher's exact test } \\
P=0.0001\end{array}$} \\
\hline No & $335(72.0 \%)$ & $130(28.0 \%)$ & 465 (93.0\%) & \\
\hline Total & $370(74.0 \%)$ & $130(26.0 \%)$ & 500 & \\
\hline
\end{tabular}

